\title{
5. COMMISSION DES ANALYSES DE TRAVAUX ET DE BIBLIOGRAPHIE
}

Président: Dr J. Kleczek, Astronomical Institute, Czechoslovak Academy of Sciences, Ondřejov, Czechoslovakia.

Vice-Président: Dr J. B. Sykes, 20 Milton Lane, Steventon, Abingdon, Berkshire, England. Membres: Alter, Baldet, Beer, Belorizky, Bourgeois, Bouska, Brasch, Collinder, Dermul, Fricke, Guyot $\dagger$, Harwood, Heinemann, Henn, Luplau-Janssen, Martynov, Ogorodnikov, Pecker (J.-C.), Rigaux, Sticker, Witkowski, Zinner.

The aim of the Commission is to improve the means of communication of astronomical knowledge. This is an important task in view of the large number of astronomical papers published each year. The form of papers, their publication and abstracting are of primary concern to the Commission.

Form of papers. UNESCO has prepared a two-page Guide for the preparation of synopses (2) which has been officially adopted by the International Council of Scientific Unions. In preparing abstracts of papers, authors should follow the advice of that document.

Rules have been laid down in $A$ code of goad practice for scientific publication (I) which should be morally binding on every author of a scientific publication as well as on every editor of a scientific journal.

It is of vital importance for scientific documentation to adopt uniform international standards applicable throughout the world. These standards will make it possible to arrive at a single code for the abbreviation of titles of scientific periodicals, a single code for symbols and abbreviations of technical terms, and a single system for the transliteration of the characters of one alphabet into those of another. Such standards are in preparation as official documents of UNESCO. Concerning specifically astronomical symbols and notation, see the lists of recommendations in earlier volumes of the Transactions $(3,4)$.

A new institute, the Zentralstelle für Terminologieforschung und praktische Sprachfragen at the University of Bonn, is able to deal with problems of terminology and also of transliteration.

Publication of papers. Many astronomical papers are published in well-established and widelydistributed journals, which form part of the library of every astronomical institute or observatory.

There are, however, a growing number of papers published in an inefficient way:

(a) papers from private laboratories,

(b) pre-prints not followed by a paper in an important journal,

(c) those published separately and with an irregular distribution,

(d) scientific reports not published in an important journal.

Such ways of publication can only lead to confusion. It would help, however, if in each country one journal could regularly publish abstracts of such marginal publications.

Astronomical bibliography. The four important abstracting journals (5) have continued to abstract world literature on astronomy on a routine basis. It should be emphasized that it is very desirable to send one copy of each marginal publication to the editor of each abstracting journal.

The Engelgardt Astronomical Observatory and the Sternberg Astronomical Institute have now completed the Bibliography of spectroscopic binaries. The third series $\left(12^{\mathrm{h}}-18^{\mathrm{h}}\right)$ has been 
printed and sent out to all institutions and persons concerned. The fourth series $\left(18^{\mathrm{h}}-24^{\mathrm{h}}\right)$ is being printed at present (November 1963).

At the Engelgardt Astronomical Observatory work is continuing on the bibliography of eclipsing variable stars.

Dr Schneller has continued the publication of the Bibliography of variable stars designated between $193^{8}$ and $195^{8}(6)$.

Mrs N. B. Lavrova from the Sternberg Astronomical Institute has compiled a useful guide to bibliographies available in astronomy (7). The work covers $3^{\mathrm{r}} 3$ astronomical bibliographies appearing in the last two centuries, beginning with the first special astronomical bibliography from the year 1755 , up to the end of 1960 . It contains detailed descriptions of general astronomical bibliographies and brief descriptions of special bibliographies in astronomy (i.e. those covering individual specific problems). This valuable reference book has been sent out to all astronomical observatories and institutes.

An important document about abstracting was published recently by UNESCO, Survey on the organization and functioning of abstracting services in the various branches of science and technology (8).

A list of contemporaneous bibliographies by Dr B. Sticker (9) might be useful also for astronomers, although its scope is much broader.

The Bibliography of Astronomy, 188I-1898 is one of the primary goals of Commission 5. A huge amount of work has been done by astronomers in abstracting astronomical publications of the period mentioned. The material ought to be published soon, even though it is not quite complete. However, there are good prospects that some important contributions previously lacking will be completed during the year I964. The National Committees for Astronomy bear full responsibility for the completion of their country's bibliography. One cannot wait for ever and leave unpublished the useful material already assembled. It is not only a question of prestige, but also of good international collaboration in the field of astronomy.

Renaming of Commission 5. The Executive Committee of the IAU has proposed to change the Commission into a Committee of the Executive Committee, with a restricted number of active members appointed by the Executive Committee itself. The aim is a closer collaboration between the Executive Committee and its Committees. However, the Executive Committee has already an important role in appointing the members of Commission 5. Some members therefore feel that the change is of no importance in itself, except for the awkwardness of the new name.

In some countries the young astronomer has to know at least two foreign languages. This is a good practice. The introduction of this practice by all nations (not only the small ones) would solve some of our problems. It would also lead to a better understanding between astronomers from all over the world.

J. KLECZEK

President of the Commission

\section{BIBLIOGRA PHY}

I. UNESCO/NS/177, I6 July 1962 .

2. UNESCO/NS $/ 37 \mathrm{D}$, roa.

3. Trans. $I A U 6,345-355,1938$.

4. Trans. $I A U$ 9, 66, 1955. 
5. Abstracts journals:

Astronomischer Fahresbericht, Astronomisches Rechen-Institut, 69 Heidelberg, Mönchhofstrasse 12-14, Federal Republic of Germany.

Bulletin signalétique du Centre National de la Recherche Scientifique: L'astronomie et physique $d u$ globe, Centre de Documentation du CNRS, 15 Quai Anatole France, Paris $7^{\ominus}$, France.

Physics abstracts, Institution of Electrical Engineers, Savoy Place, London W.C.2., England.

Referationy zhurnal, Institute of Scientific and Technical Information, Baltijsky pos. $42 \mathrm{~b}$, Moscow, U.S.S.R.

6. Schneller, H. Geschichte und Literatur des Lichtwechsels der veränderlichen Sterne, 2. Ausgabe, 5. Band, Akademie-Verlag, Berlin: Heft 2 (Delphinus bis Perseus), 1962; Heft 3 (Phoenix bis Vulpecula), 1963.

7. Lavrova, N. B. Bibliografija astronomičeskih bibliografij, Astronomical Council of the U.S.S.R. Academy of Sciences, Moscow, 1962.

8. UNESCO E/36r8, 24 April 1962, 264 pages.

9. Sticker, B. Verzeichnis der wichtigen laufend erscheinenden Bibliographien, Verlag F. Steiner, Wiesbaden, 1963. 